\title{
DERAJAT KEASAMAN (pH) VINEGAR DALAM MEDIA LIMBAH FERMENTASI BIJI KAKAO AKIBAT PENAMBAHAN KONSENTRASI Acetobacter aceti DAN WAKTU INKUBASI
}

\author{
Wiwik Kusmawati \\ IKIP Budi Utomo Malang \\ Email: wiwikkusmawati@gmail.com
}

\begin{abstract}
ABSTRAK
The study was aimed to identify the degree of acidity $(\mathrm{pH})$ vinegar in a medium waste fermentation of cocoa beans due to the addition of Acetobacter aceti concentration and time of incubation.This research utilised two factor, factorial design with completely randomized design (CRD). Thefirst factor is the Acetobacter aceti consentration (10\%, $13 \%$, dan 16\%). The second is the time of incubation (6, 8, dan 10 day). Results were analyzed by using SPSS program version 11 personal computer, two way ANOVA and multiple comparison test with significance level of 0,05.The results of analysis of variance showed that there were differences in the degree of acidity $(\mathrm{pH})$ of vinegar in a medium waste fermentation of cocoa beans due to the addition of Acetobacter aceti concentration and time of incubation. While Duncan's test results showed the treatment inoculation 13\% starter Acetobacter aceti with 6 days of incubation time significantly different from the other treatments with minimal $\mathrm{pH}$ is 2,02. So that these results meet the standards of vinegar. From these experiment we suggested that consentration of Acetobacter aceti and incubation period has effects in the degree of acidity $(\mathrm{pH})$ vinegar in fermentation waste of cacao seed medium.

Keywords: Degree of acidity ( $(\mathrm{HH})$, fermentation waste of cacao seed medium, Acetobacter aceti.
\end{abstract}

\section{PENDAHULUAN}

Vinegar merupakan salah satu asam organik yang paling penting karena banyak digunakan dalam industri untuk memproduksi asam-asam alifatis, pembuatan obat-obatan (aspirin), pembuatan warna (indigo) dan parfum (Tjokroadikoesoemo, 1993). Sedangkan vinegar dalam industri makanan berfungsi sebagai agen anti mikrobial dan meningkatkan cita rasa (Douglas dan Glen, 1982).

Menurut Rahman (1992) vinegar dapat dibuat dari bahan baku yang mengandung gula, termasuk juga dari limbah fermentasi biji kakao. Apalagi perkembangan luas tanaman kakao pada Pelita V lebih dari 400.000 hektar. Sehingga dapat diperhitungkan produksi kakao di Indonesia akan mencapai sekitar 250.000 ton di akhir tahun 1990-2000 (Anonymous, 1988).

Tersedianya bahan baku yang cukup melimpah menunjukkan bahwa Indonesia sangat berpotensi untuk mengembangkan produksi vinegar. Namun, pada kenyataannya sampai saat ini Indonesia masih mengimpor vinegar yang cukup besar.

Limbah fermentasi biji kakao diperoleh sesudah biji kakao difermentasi. Lama waktu fermentasi biji kakao tergantung pada jenis kakao yang akan difermentasi. Fermentasi dimaksudkan untuk memperoleh biji kakao kering dengan aroma dan warna yang disukai konsumen. Selama itu pula enzim menguraikan senyawa polifenol, protein dan gula yang selanjutnya akan menghasilkan senyawa aroma, perbaikan cita rasa dan perubahan warna (Iswanto, 1997).

Pada akhir fermentasi timbul bau asam cuka yang keras dan pulp mudah dilepaskan. Melepasnya pulp dari biji menghasilkan cairan yang selain merembes ke dalam biji, juga mengalir keluar melalui lubang kotak fermentasi (Alamsyah, 1991).

Cairan ini merupakan limbah yang berasal dari pulp dan belum dimanfaatkan atau dibuang begitu saja. Menurut Ardhana (1990) biji kakao yang telah difermentasi selama 18 jam akan menghasilkan cairan dengan kadar etanol sampai $12 \%$, glukosa sampai $8 \%$, sukrosa $6,1 \%$ dan asam asetat sampai 5,27\%. Sedangkan Junianto (1995) mengatakan limbah ini menghasilkan asam asetat $0,22 \%$, alkohol 3,9\% dan gula reduksi $17,299 \%$.

Terbentuknya vinegar memerlukan dua proses. Proses pertama adalah pengubahan gula menjadi alkohol oleh khamir (fermentasi 
alkoholik). Proses kedua adalah pengubahan etanol menjadi asam asetat oleh bakteri asam asetat (fermentasi oksidatif) (Frazier dan Westhoff, 1983).

Menurut Desrosier (1977) pada fermentasi oksidatif, starter atau bibit yang cocok harus ditambahkan untuk menyediakan jenis bakteri yang diperlukan. Starter yang baik adalah berasal dari biakan murni (Sa'id, 1987). Strain yang digunakan untuk produksi asam asetat adalah Acetobacter aceti karena kemampuannya dibawah kondisi aerasi dan keasaman yang tinggi mengubah etanol secara cepat dengan hasil asam asetat tinggi (Crueger dan Anneliese, 1992). Sehingga penelitian mengenai galur Acetobacter aceti yang dapat mengubah etanol menjadi asam asetat dapat menjadikan cara pembuatan asam cuka dengan fermentasi oksidatif menjadi penting kembali (Sardjoko, 1991).

Pemberian starter dilakukan dengan cara menuangkan hasil biakan bakteri Acetobacter aceti ke dalam fermentor. Menurut Wibowo et al. (1990) proporsi starter pada umumnya 3-10\% dibanding volume total media. Persiapan starter dilakukan agar fase adaptasi dalam media fermentasi seminimal mungkin, sehingga proses fermentasinya berlangsung lebih cepat. Sedangkan Purwaningsih (1989) mengatakan starter Acetobacter aceti yang ditambahkan pada fermentor kurang lebih sebanyak 10\% dari volume medium. Rahman (1992) mengatakan pada pembuatan vinegar dari aren nira, starter yang ditambahkan kurang lebih sebanyak 20\% dari volume medium. Dan waktu inkubasi akan memperbaiki cita rasa dan kadar asam asetat yaang dihasilkan (Desrosier, 1977).

Selama fermentasi oksidatif itu Acetobacter aceti mengoksidasi etanol dan menghasilkan asam asetat. Starter Acetobacter aceti 11,5\% akan menghasilkan kadar asam asetat 5\% dan efisiensi pengubahan sekitar 86\% (Pudjiraharti et al., 1988). Penelitian yang dilakukan oleh Kusmawati (1999) inokulasi $13 \%$ starter Acetobacter aceti dengan waktu inkubasi 6 hari berbeda nyata dengan perlakuan lain dengan kadar asam asetat maksimal yaitu 4,02\%.

Di samping itu selama fermentasi, $\mathrm{pH}$ berubah menurun. Penurunan $\mathrm{pH}$ terjadi apabila memproduksi asam-asam organik misalnya asam asetat, asam laktat dan lain-lain (Sa'id, 1987). Perubahan $\mathrm{pH}$ yang terjadi pada medium fermentasi masih dalam batas toleransi optimum untuk proses fermentasi aerob dan pertumbuhan Acetobacter aceti yakni 3,0-4,0 sehingga tidak perlu penambahan buffer (Pudjiraharti et al., 1988). Standar $\mathrm{pH}$ vinegar yaitu 2,0-4,0 (Sa'id, 1987). Sedangkan menurut Holt et al. (1994) mengatakan $\mathrm{pH}$ vinegar yang diperoleh adalah $4,0-5,0$.

Berdasarkan uraian di atas, penting untuk dilakukan penelitian tentang Derajat Keasaman (pH) Vinegar dalam Media Limbah Fermentasi Biji Kakao Akibat Penambahan Konsentrasi Acetobacter aceti dan Waktu Inkubasi.

\section{METODE PENELITIAN}

\section{Pengambilan Sampel}

Sampel diambil dengan cara menampung tetesan limbah fermentasi biji kakao pada lembaran plastik yang diletakkan di bawah kotak fermentasi biji kakao. Plastik ini dipasang sejak biji kakao yang baru dipetik, dimasukan ke dalam kotak fermentasi. Plastik dipasang sekitar 18 jam untuk menampung limbah yang mengalir dari kotak fermentasi, limbah yang tertampung dalam plastik dimasukkan ke dalam botol-botol kaca steril. Botol-botol ini ditutup dengan aluminium foil dan plastik. Kemudian dimasukan di dalam termos yang telah diisi dengan es dan dibawa ke Laboratorium Biologi Universitas Muhammadiyah Malang.

\section{Pemeliharaan Kultur}

Untuk fermentasi alkoholik digunakan kultur murni Saccharomyces cerevisiae yang dipelihara pada media Malt Extract Agar Miring selama 24 jam pada suhu $30^{\circ} \mathrm{C}$. Sedangkan untuk fermentasi oksidatif digunakan Acetobacter aceti yang dipelihara padamedia agar miring selama 24 jam pada suhu $30^{\circ} \mathrm{C}$.

\section{Pembuatan Starter}

Untuk fermentasi alkoholik kultur Saccharomyces cerevisiae yang telah ditanam pada media Malt Extract Agar Miring diambil 2 ose dan diinokulasikan ke dalam $578 \mathrm{ml}$ media limbah fermentasi biji kakao yang telah dipasteurisasi selama 15 menit pada suhu $72^{\circ} \mathrm{C}$. Selanjutnya diaerasi 12-14 gelembung per menit dan diinkubasi selama 24 jam pada suhu kamar $\left(25-29^{\circ} \mathrm{C}\right)$. Setelah inkubasi media ini dipakai sebagai starter.

Untuk fermentasi oksidatif biakan murni Acetobacter aceti yang telah ditanam pada media agar miring diambil 2 ose dan diinokulasikan ke dalam $5 \mathrm{ml}$ media cair dan diinkubasi selama 24 jam pada suhu $30^{\circ} \mathrm{C}$. Setelah waktu yang ditentukan tercapai, dari media cair diinokulasikan ke dalam $150 \mathrm{ml}$ media limbah fermentasi biji kakao yang telah 
dipasteurisasi selama 15 menit pada suhu $72^{\circ} \mathrm{C}$. Kultur ini kemudian diaerasi 12-14 gelembung per menit dan diinkubasi selama 18 jam pada suhu kamar. Setelah inkubasi media ini dipakai sebagai starter.

\section{Proses Fermentasi}

Limbah fermentasi biji kakao yang telah diperoleh dimasukkan pada botol (sebagai fermentor alkoholik) sebanyak $1000 \mathrm{ml}$ secara aseptis dan dipasteurisasi pada suhu $72^{\circ} \mathrm{C}$ selama 15 menit. Kemudian didinginkan sampai sekitar $30-31^{\circ} \mathrm{C}$.

Setelah dingin $\left(30^{\circ} \mathrm{C}\right)$ diinokulasi dengan starter Saccharomyces cerevisiae sebanyak $10 \%$ dari volume substrat dalam fermentor $(=100$ ml) dan ditutup dengan kapas, diinkubasi pada suhu $30^{\circ} \mathrm{C}$ selama 3 hari atau sampai pembentukan gelembung $\mathrm{CO}_{2}$ berhenti.

Agar tidak menganggu proses fermentasi selanjutnya, Saccharomyces cerevisiae yang terdapat pada fermentor dimatikan terlebih dahulu, dengan cara substrat bersama fermentor dipasteurisasi pada suhu $72^{\circ} \mathrm{C}$ selama 15 menit. Disamping itu diamati pula apakah Saccharomyces cerevisiae telah mati atau belum dengan cara mengamati dibawah mikroskop, menggunakan pewarnaan larutan methylen blue. Apabila Saccharomyces cerevisiae yang ditemukan ternyata masih hidup, ditunjukkan dengan warna jernih maka lama pasteurisasi ditambah hingga tidak ditemukan lagi adanya Saccharomyces cerevisiae yang masih hidup. Setelah proses fermentasi alkoholik berakhir dilakukan pengambilan sampel dan pengukuran kadar alkohol.
Untuk menuju proses oksidasi etanol menjadi asam asetat, substrat yang telah dipasteurisasi pada suhu $72^{\circ} \mathrm{C}$ selama 15 menit, dalam keadaan panas substrat dipindahkan ke dalam botol fermentor untuk fermentasi oksidasi yang sudah disterilkan terlebih dahulu sebanyak $100 \mathrm{ml}$. Substrat yang telah dingin diinokulasi dengan starter Acetobacter aceti secara aseptis dengan perlakuan:

$1=$ Konsentrasi Acetobacter aceti $10 \%$ dari volume substrat

$2=$ Konsentrasi Acetobacter aceti $13 \%$ dari volume substrat

$3=$ Konsentrasi Acetobacter aceti $16 \%$ dari volume substrat

Kemudian diaerasi 12-14 gelembung per menit dan diinkubasi pada suhu kamar. Pengukuran kadar asam asetat dilakukan pada hari ke-6, ke-8 dan ke-10.

\section{Pengukuran pH}

Pengukuran $\mathrm{pH}$ dilakukan dengan cara mengukur langsung sampel yang baru diambil dengan $\mathrm{pH}$ meter.

\section{Analisis Data}

Jika data berdistribusi normal dan varian datanya homogen, maka data tersebut dianalisis dengan analisis sidik ragam dan uji beda jarak nyata Duncan's.

\section{HASIL PENELITIAN DAN PEMBAHASAN}

Berdasarkan dari hasil penelitian diperoleh data sebagai berikut:

Tabel 1 Derajat keasaman $(\mathrm{pH})$ vinegar hasil fermentasi oksidatif limbah fermentasi biji kakao

\begin{tabular}{|l|l|l|l|l|l|}
\hline Perlakuan & \multicolumn{3}{|c|}{ Ulangan } & \multirow{2}{*}{ Total } & Rerata \\
\cline { 1 - 3 } & I & II & III & & \\
\hline $\mathrm{A}_{1} \mathrm{~W}_{1}$ & 2,12 & 2,88 & 2,23 & 7,23 & 2,5 \\
\hline $\mathrm{A}_{1} \mathrm{~W}_{2}$ & 2,13 & 2,47 & 2,9 & 7,5 & 2,73 \\
\hline $\mathrm{A}_{1} \mathrm{~W}_{3}$ & 2,23 & 3,02 & 3,02 & 8,27 & 3,55 \\
\hline $\mathrm{A}_{2} \mathrm{~W}_{1}$ & 1,94 & 1,99 & 2,14 & 6,07 & 2,02 \\
\hline $\mathrm{A}_{2} \mathrm{~W}_{2}$ & 2,46 & 2,85 & 2,23 & 7,54 & 2,41 \\
\hline $\mathrm{A}_{2} \mathrm{~W}_{3}$ & 2,88 & 2,82 & 2,47 & 8,17 & 3,22 \\
\hline $\mathrm{A}_{3} \mathrm{~W}_{1}$ & 3,54 & 4,23 & 4,38 & 12,15 & 2,5 \\
\hline $\mathrm{A}_{3} \mathrm{~W}_{2}$ & 3,54 & 3,46 & 3,64 & 10,64 & 2,76 \\
\hline $\mathrm{A}_{3} \mathrm{~W}_{3}$ & 3,28 & 3,28 & 3,09 & 9,65 & 4,05 \\
\hline Total & 24,12 & 27 & 26,10 & 77,22 & 25,73 \\
\hline
\end{tabular}




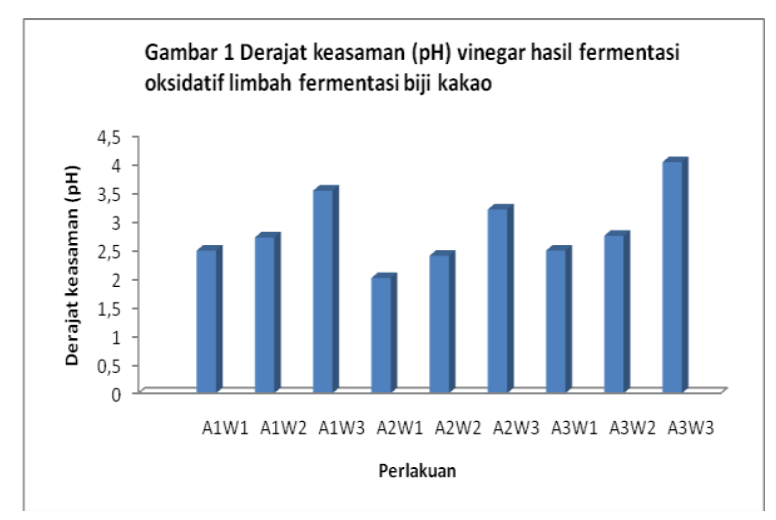

Keterangan:

$\mathrm{A}_{1} \mathrm{~W}_{1}=$ Inokulasi $10 \%$ Acetobacter aceti dan waktu inkubasi selama 6 hari.

$\mathrm{A}_{1} \mathrm{~W}_{2}=$ Inokulasi $10 \%$ Acetobacter aceti dan waktu inkubasi selama 8 hari.

$\mathrm{A}_{1} \mathrm{~W}_{3}=$ Inokulasi $10 \%$ Acetobacter aceti dan waktu inkubasi selama 10 hari

$\mathrm{A}_{2} \mathrm{~W}_{1}=$ Inokulasi $13 \%$ Acetobacter aceti dan waktu inkubasi selama 6 hari.

$\mathrm{A}_{2} \mathrm{~W}_{2}=$ Inokulasi $13 \%$ Acetobacter aceti dan waktu inkubasi selama 8 hari.

$\mathrm{A}_{2} \mathrm{~W}_{3}=$ Inokulasi $13 \%$ Acetobacter aceti dan waktu inkubasi selama 10 hari.

$\mathrm{A}_{3} \mathrm{~W}_{1}=$ Inokulasi $16 \%$ Acetobacter aceti dan waktu inkubasi selama 6 hari.

$\mathrm{A}_{3} \mathrm{~W}_{2}=$ Inokulasi $16 \%$ Acetobacter aceti dan waktu inkubasi selama 8 hari.

$\mathrm{A}_{3} \mathrm{~W}_{3}=$ Inokulasi $16 \%$ Acetobacter aceti dan waktu inkubasi selama 10 hari.

Hasil analisis sidik ragam menunjukkan bahwa ada perbedaan derajat keasaman $(\mathrm{pH})$ vinegar dalam media limbah fermentasi biji kakao akibat penambahan konsentrasi Acetobacter aceti dan waktu inkubasi. Sedangkan hasil uji Duncan's 5\% menunjukkan perlakuan inokulasi 13\% starter Acetobacter aceti dengan waktu inkubasi 6 hari berbeda nyata dengan perlakuan lain dengan $\mathrm{pH}$ minimal yaitu 2,02.

Perbedaan kadar asam asetat yang dihasilkan pada tiap perlakuan menyebabkan $\mathrm{pH}$ yang diperoleh juga berbeda, yaitu sekitar 2,02-4,05. Perubahan $\mathrm{pH}$ ini masih dalam kisaran $\mathrm{pH}$ untuk vinegar, sehingga telah memenuhi standar $\mathrm{pH}$ vinegar yaitu 2,0-4,0 (Sa'id, 1987). Sedangkan menurut Holt et al. (1994) mengatakan pH vinegar yang diperoleh adalah 4,0-5,0.

Ada beberapa faktor yang mempengaruhinya antara lain: jenis senyawa dan aktivitas Acetobacter aceti. Alkohol adalah senyawa hidroksida yang bersifat polar atau mudah menguap dan merupakan basa lemah yang memiliki pH 8,0-9,0. Ini berarti kadar alkohol dalam medium berpengaruh terhadap peningkatan $\mathrm{pH}$. Sehingga semakin tinggi kadar alkohol dalam medium $\mathrm{pH}$ semakin meningkat begitu pula sebaliknya.Sedangkan asam asetat merupakan senyawa karboksilat yang mempunyai sifat sebagai asam lemah. Apabila dalam medium terjadi penambahan asam atau asam asetat maka akan terjadi penurunan $\mathrm{pH}$.

Selama fermentasi oksidatif ini Acetobacter aceti mengoksidasi alkohol menjadi asam asetat dan air yang menyebabkan kadar alkohol menurun. Sesuai dengan kadar asam asetat yang terbentuk semakin berkurangnya kadar alkohol karena proses tersebut menjadikan sifat basa dalam medium berkurang dan sebaliknya meningkatkan derajat asamnya, yang ditandai dengan penurunan $\mathrm{pH}$. Maka pada perlakuan inokulasi $13 \%$ Acetobacter aceti karena mempunyai kadar asam asetat maksimal dibandingkan dengan perlakuan inokulasi $10 \%$ dan $16 \%$ Acetobacter aceti menyebabkan $\mathrm{pH}-$ nya juga lebih rendah.

Disamping itu oksidasi asam asetat menjadi karbon dioksida dan air menyebabkan karbon dioksida akan dilepas sebagai gas dan air akan tetap berada dalam medium. Dengan demikian kadar alkohol akan terus menurun sampai pada pengamatan terakhir, sehingga $\mathrm{pH}$ mengalami perbedaan.

Bahkan Fessenden dan Fessenden (1986) mengatakan adanya asam asetat dan alkohol bersama-sama dalam media menyebabkan terbentuknya senyawa ester. Dengan terbentuknya senyawa ester ini menyebabkan pH mengalami perbedaan. Reaksi terbentuknya senyawa ester dari alkohol dan asam asetat adalah sebagai berikut: 


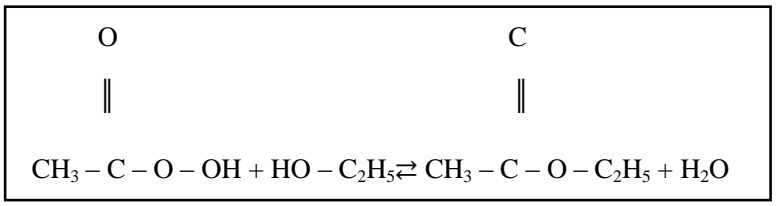

\section{Kesimpulan}

Dari hasil penelitian dapat disimpulkan bahwa ada perbedaan derajat keasaman $(\mathrm{pH})$ vinegar dalam media limbah fermentasi biji kakao akibat penambahan konsentrasi Acetobacter aceti dan waktu inkubasi.

\section{DAFTAR PUSTAKA}

Anonymous. 1988. Bercocok Tanam Kakao. Dinas Perkebunan Daerah Propinsi Dati I Jawa Timur, Jawa Timur.

Alamsyah, T. S., 1991, Peranan Fermentasi dalam Pengolahan Biji Kakao Kering, Puslit Jember, Jember.

Ardhana, 1990, Microbial Ecology and Biochemistry of Cocoa Bean Fermentation, Sinauer Ass. INC., Sunderland.

Crueger, W., C., Anneliese, 1984, Biotechnology: A Text book of Industrial Microbiology, Sinauer Ass. INC., Sunderland.

Desrosier, N. W., J. N., Desrosier, 1977, The Technology of Food Preservation, Fourth Edition, The Avi Publ. Companyy Inc., Connecticut.

Frazier, W. C., D. C., Westhoff, 1988, Food Microbiology, McGraw-Hill Book Company, Singapore.

Holt, J. G., Krieg, N. R., Sneath, P. H. A., Staley, J. T., dan Williams, S. T., 1994, Bergey's Manual of Determinative Bacteriology, Ninth edition, Williams and Wilkins, Baltimore, Maryland.

Iswanto, H., 1997, Fermentasi Biji Kakao Menentukan Cita Rasa Coklat Sejati, Trubus 328-Thn. XXIII-Maret 1997, Jakarta.

Kusmawati, W., 1999, Analisis Kadar Asam Asetat Vinegar dalam Media Limbah Fermentasi Biji Kakao Akibat Pengaruh Konsentrasi Acetobacter aceti dan Waktu Inkubasi, Universitas Muhammadiyah Malang, Malang.

Rahman, A., 1992, Teknologi Fermentasi, Penerbit Arcan, Jakarta.

Sa'id, E. G., 1987, Bioindustri: Penerapan Teknologi Fermentasi, Penerbit Pusat Antar Universitas (PAU) Biotek IPB bekerjasama dengan PT Mediyatama Sasana Perkasa, Jakarta.

Sardjoko, 1991, Bioteknologi: Latar Belakang dan Penerapannya, PT Gramedia Pustaka Utama, Jakarta.

Schlegel, H. G., Schmidt, 1994, Mikrobiologi Umum, UGM Press, Yogyakarta.

Tjokroadikoesoemo, P. S., 1993, HFS dan Industri Ubi Kayu Lainnya, PT Gramedia Pustaka Utama, Jakarta.

Wibowo, D., 1990, Teknologi Fermentasi, Pusat Antar Unoversitas-Pangan dan Gizi UGM, Yogyakarta. 